Jurnal Anugerah, 2(2) (2020)
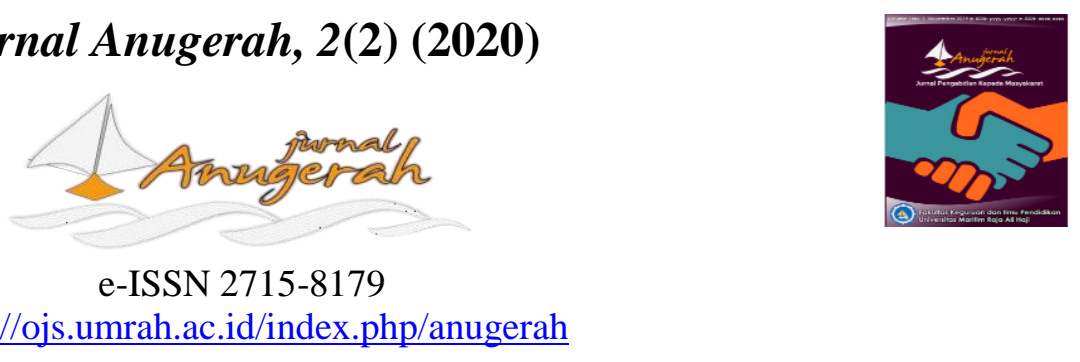

https://ojs.umrah.ac.id/index.php/anugerah

\title{
Sosialisasi Pendidikan Karakter di Lingkungan Keluarga Masyarakat Kelurahan Kampung Bugis, Kota Tanjungpinang
}

\author{
Abdul Malik ${ }^{*}$, Isnaini Leo Shanty ${ }^{1}$, Hilfi Pardi² \\ ${ }^{1}$ Program Studi Pendidikan Bahasa dan Sastra Indonesia \\ ${ }^{2}$ Program Studi Pendidikan Kimia \\ Universitas Maritim Raja Ali Haji, Tanjungpinang, Kepuluan Riau, 29122, Indonesia \\ *e-mail korrespondensi: abdulmalik@umrah.ac.id
}

Pengiriman: 15 Oktober 2020; Diterima: 29 Oktober 2020; Publikasi: 30 November 2020

DOI: https://doi.org/10.31629/anugerah.v2i2.2642

\begin{abstract}
Abstrak
Tujuan kegiatan pengabdian masyarakat ini adalah (1) menyosialisasikan pendidikan karakter kepada warga Kampung Bugis Kota Tanjungpinang, dan (2) membandingkan pemahaman mereka antara sebelum dan sesudah diberikan sosialisasi tentang pendidikan karakter. Pendekatan yang digunakan berupa sosialisasi dengan ceramah, tanya jawab, pemberian contoh, dan diskusi. Teknik analisis data yang digunakan adalah metode kualitatif. Kegiatan ini berhasil meningkatkan pengetahuan, pemahaman, dan keterampilan masyarakat Kampung Bugis dalam melaksanakan pendidikan karakter bagi anak-anak mereka.
\end{abstract}

Kata kunci: anak-anak; keluarga; masyarakat; pendidikan karakter; sosialisasi

\begin{abstract}
This activity of community service aims at (1) providing socialization about character education to the family in Kampung Bugis, Tanjungpinang City and (2) comparing the understanding about character education in the family before and after socialization about character education. The approach used is socialization by lecturing, giving questions and answers, giving examples, and discussing. The data analysis technique used is a qualitative method. The result of this activity was increasing knowledge, understanding, and skills of the community in Kampung Bugis about implementing character education for their children.
\end{abstract}

Keywords: character education; children; community socialization; family

\section{Pendahuluan}

Pendidikan karakter, oleh pemerintah, dijadikan sasaran utama pengembangannya sekarang. Berhubung dengan itu, guna menyukseskan Program Indonesia Emas 2045, pembelajaran kepribadian diharapkan menjadi landasan utamanya sehingga pembelajaran karakter merupakan bagian terpenting dalam proses pembangunan akhlak anak bangsa.

Pendidikan — sesuai dengan UU Nomor 20 Tahun 2003 tentang Sistem Pembelajaran Nasional, Pasal 13, ayat 1-terdiri atas jalur pembelajaran formal, nonformal, serta informal (Departemen Pendidikan Nasional [Depdiknas], 2003). Lewat jalan pembelajaran informal, dilaksanakan pembelajaran keluarga. Pembelajaran informal berfungsi serta berkontribusi yang sangat mustahak dalam keberhasilan pembelajaran. Hal ini karena realitas $70 \%$ waktu dihabiskan peserta didik dalam keluarga serta 


\section{JURNAL ANUGERAH, November 2020; Vol 2(2): 67 - 74}

\section{e-ISSN 2715-8179}

lingkungannya. Mereka lebih banyak berada di wilayah pembelajaran informal dibandingkan dengan pembelajaran formal serta nonformal.

Kenyataannya, selama ini pendidikan informal belum memberikan sumbangan yang signifikan dalam menunjang tercapainya kompetensi serta pembentukan kepribadian peserta didik. Keadaannya menjadi genting karena karakter pribadi peserta didik kita menunjukkan kondisi yang sangat mengkhawatirkan, terkhusus di sebagian tempat atau daerah Indonesia (Malik, Dahnuss, \& Shanty, 2019). Gejala itu menjadi sorotan media (cetak serta elektronik), yang kerap menyajikan rekaman yang menyeramkan tentang pelbagai kekerasan yang terjadi akibat tingkah laku negatif peserta didik. Kekerasan yang dimaksudkan meliputi perundungan, pencurian, pengedaran narkotika dan obat terlarang, dan pelbagai kejahatan serta perilaku menyimpang lainnya. Perkelahian antarsiswa pun sering terjadi. Di banyak sekolah serta banyak tempat terdapat peserta didik menunjukkan sikap mengajak gurunya berkelahi. Kesemuanya itu menjadi permasalahan bangsa, yang pemecahannya wajib diupayakan sebaik, sebijak, setepat, dan secepat mungkin secara bersama-sama.

Melalui Departemen Pendidikan Nasional, pemerintah sudah merancang pembelajaran karakter dengan perencanaan berskala nasional sejak 2010-2014. Dari rencana itu ditegaskan bahwasanya pendidikan karakter merupakan pembelajaran nilai, pembelajaran budi pekerti, moral, serta watak. Tujuan pendidikan yang disebut juga pendidikan budi pekerti ini untuk meningkatkan keahlian peserta didik dalam menentukan keputusan tentang nilai-nilai positif-negatif, mempertahankan nilai positif, serta mempraktikkan kebajikan dan kemuliaan yang telah diperoleh dalam pergaulan hidup dengan penuh tanggung jawab (Kementerian Pendidikan Nasional, 2010).

Pemerintah, kali ini melalui Kemendikbud, juga telah menetapkan 3 guna pendidikan budaya serta karakter bangsa. Ketiganya meliputi (1) pengembangan, yakni untuk mengembangkan kemampuan pembelajar agar berkembang sebagai individu berkelakuan elok bagi para siswa yang perilaku dan sikapnya telah menunjukkan nilai budaya dan kepribadian Indonesia; (2) perbaikan, yakni menguatkan kedudukan kependidikan Indonesia untuk senantiasa memberikan perhatian utama bagi peningkatan kemampuan para siswa sehingga martabat mereka terangkat; serta (3) penyaring, yakni upaya menapis nilai-nilai budaya nusantara serta budaya asing yang bertentangan dengan keluhuran dan kepribadian Indonesia yang beradab.

Seluruh kejadian negatif yang diperikan di muka berpotensi memengaruhi pertumbuhan karakter pembelajar tersebut. Untuk menangkal peristiwa negatif itu, dibutuhkan uraian tentang metode menanam serta meningkatkan karakter meliputi pembelajaran-pembelajaran nilai, budi pekerti, moral, serta watak di dalam keluarga (Malik, Dahnuss, \& Shanty, 2019; Malik \& Shanty, 2017; Pusat Kurikulum, 2010).

Lickona, (2004) secara substantif mengatakan ada 3 bentuk tingkah laku yang saling berhubungan: (1) moral knowing; (2) moral feeling; serta (3) moral behavior. Selain itu, keluarga ialah faktor internal yang sangat memengaruhi pertumbuhan kepribadian generasi di keluarga tersebut. Akan tetapi, ada juga pemikiran yang berbeda. Dalam konteks ini, penentu utama baik-tidaknya anak terletak pada pendidik formal di sekolah.

Waktu terbanyak kanak-kanak digunakan untuk berinteraksi dengan keluarga serta masyarakat sekitarnya. Mereka menyimpan dengan baik di dalam ingatan seluruh peristiwa dalam kehidupan sehari-hari. Kesemuanya ini sangat sensitif bila yang terekam itu banyak yang negatif. Oleh karena itu, kedudukan orang tua sangat dipelukan bagi mengestimasi gejala tersebut. Atas dasar itulah, sangat dibutuhkan penanaman nilai pendidikan karakter semenjak dini pada kanak- kanak di dalam keluarga (Malik, 2014, 2015a). Berdasarkan hal tersebut, aktivitas pengabdian ini difokuskan pada keluarga warga Kelurahan Kampung Bugis, Kecamatan Tanjungpinang Kota, Kota Tanjungpinang.

Permasalahan yang diangkat dalam aktivitas pengabdian ini meliputi dua isu utama: (1) bagaimanakah pemahaman orang tua tentang pendidikan karakter sebelum diberikan sosialisasi; (2) apakah ada peningkatan pemahaman orang tua tersebut tentang pendidikan karakter di dalam keluarga? 
Sesuai dengan rumusan permasalahan, tujuan kegiatan ini (1) menyosialisasikan pendidikan karakter di dalam keluarga; (2) menyamakan pemahaman tentang pendidikan karakter di dalam keluarga warga yang diberikan sosialisasi.

\section{Metode}

Masyarakat yang menjadi sasaran kegiatan pengabdian kepada masyarakat ini adalah warga Kelurahan Kampung Bugis, Kecamatan Tanjungpinang Kota, Kota Tanjungpinang, Provinsi Kepulauan Riau (selanjutnya disebut warga Kampung Bugis saja). Pelaksanaan efektifnya dimulai dari 2 Maret 2020 sampai dengan 30 Oktober 2020.

Berdasarkan kesepakatan untuk menyelesaikan permasalahan yang ada, maka tim PkM menggunakan metode pendekatan sosialisasi. Kegiatan dilakukan di rumah tokoh masyarakat setempat. Kegiatan ini didukung oleh narasumber yang ahli dalam bidang pendidikan karakter. Bentuk kegiatannya adalah ceramah, diskusi, dan pelatihan.

Tolok ukur yang digunakan sebagai pengukur (indicator) tercapainya tujuan PkM dikemukakan berikut ini.

$1.80 \%$ undangan menghadiri aktivitas PkM ini.

$2.100 \%$ aktivitas sosialisasi terlaksana.

$3.75 \%$ peserta menyatakan puas terhadap sosialisasi yang diberikan.

4.50\% peserta mampu menerapkan ilmu yang didapatkan dalam kegiatan PkM, yang didampingi oleh tim PkM.

\section{Hasil dan Pembahasan}

Aktivitas PkM yang dilakukan ini berbentuk sosialisasi penerapan pendidikan karakter di dalam keluarga. Kegiatannya berlangsung di kalangan warga Kampung Bugis. Ada 18 nilai budi pekerti yang diperkenalkan kepada keluarga peserta sosialisasi, yaitu nilai-nilai ketuhanan, kejujuran, ketoleransian, keteraturan, bekerja keras, kreativitas, kemandirian, demokratis, keingintahuan, semangat kebangsaan, mencintai negara, berwawasan keunggulan, suka berteman/mahir berkomunikasi, menyukai kedamaian, rajin membaca-menulis, kepedulian terhadap persekitaran, kepedulian terhadap masyarakat, serta bertanggung jawab (Pusat Kurikulum, 2010; Malik, Dahnuss, \& Shanty, 2019).

Sosialisasi pelaksanaan pendidikan budi pekerti (karakter) diintegrasikan dengan berbagai kearifan lokal yang terdapat dalam kehidupan budaya masyarakat Melayu. Aspek budaya Melayu meliputi yang dirujuk meliputi (1) lagu menidurkan anak (mengulik), (2) pantun, (3) syair, (4) gurindam, (5) folklore, (6) pepatah, (7) tarian, dan (8) sandiwara Melayu (Malik, 2015a; Malik et al., 2019; Malik \& Shanty, 2017, 2019).

Serangkaian permasalahan yang telah diperikan di atas memang berpotensi terjadi pada generasi penerus atau anak-anak di Kampung Bugis jika tidak diantisipasi sebaik dan sedini mungkin. Berikut ini solusi yang ditawarkan dalam kegiatan sosialisasi.

1. Memperkenalkan delapan belas nilai karakter yang perlu diajarkan dan diimplementasikan terhadap anak-anak di lingkungan keluarga kepada masyarakat.

2. Meningkatkan kesadaran masyarakat untuk menerapkan dan membiasakan delapan belas nilai karakter di lingkungan sekitar mereka.

3. Menggalakkan keluarga, Rukun Tetangga, Rukun Warga, Karang Taruna, dan Lembaga Swadaya Masyarakat untuk menjaga lingkungan sekitar agar terhindar dari pengaruh-pengaruh negatif.

4. Menggalakkan keluarga, Rukun Tetangga, Rukun Warga, Karang Taruna, dan Lembaga Swadaya Masyarakat untuk melakukan dan memfasilitasi kegiatan-kegiatan positif bagi anak-anak. 


\section{JURNAL ANUGERAH, November 2020; Vol 2(2): 67 - 74 e-ISSN 2715-8179}

5. Melakukan pendekatan kepada keluarga-keluarga untuk selalu memberikan perhatian ekstra kepada anak-anak mereka.

6. Memfasilitasi keluarga-keluarga sasaran untuk mendapatkan pengetahuan dan penerapan terkait permasalahan yang muncul melalui kegiatan-kegiatan pengabdian kepada masyarakat.

Kegiatan PkM ini ditargetkan pada keluarga-keluarga sasaran untuk memahami 18 nilai budi pekerti (karakter), mampu menginternalisasikan dan menerapkan nilai karakter untuk mendidik anak-anak mereka, dan pada gilirannya anak-anak pula diharapkan mampu mengenal hal-hal positif dan negatif dalam pergaulan sehingga mereka menjadi pribadi yang bermental dan berkarakter hebat.

Dalam pelaksanaan kegiatan ini, tim pelaksana menyajikan bahan berkenaan dengan cara menggunakan dan menerapkan nilai budi pekerti. Penerapan nilai karakter yang ada di dalam Gurindam Dua Belas (Haji, 1846; Malik, 2015) mencakupi nilai-nilai, yaitu, (1) ketuhanan: pasal I (1-6), II (1-5), dan XII (67); (2) kejujuran: pasal III (3), IV (3, 5, 9, 11), V (2), VII (1, 3, 9, 10, 11); (3) ketoleransian: pasal IV (10), V (6), VII (5), VIII (3, 7), XI (5); (4) keteraturan: pasal pasal III (1-7), V (6); (5) bekerja keras: pasal V (2, 4, 5), VI (2), VII (6), IX (7); (6) kreativitas: pasal V (5), X (3); (7) kemandirian: pasal V (5), VII (4), X (3); (8) demokratis: pasal IV (8, 10), V (6), VII (3), X (5) XI (5), XII (1-3); (9) keingintahuan: pasal V (4-5), VI (2), IX (7); (10) semangat kebangsaan: pasal XI (1-3); (11) mencintai negara: pasal V (1), XII (3); (12) wawasan keunggulan: pasal XII (4-5); (13) berteman/mahir berkomunikasi: pasal VI (1,4-5), VII (9-10), X (5); (14) menyukai kedamaian: pasal IV (1-4, 8, 11), V (1, 3, 6), VI (1,4), VII (9-10), VIII (7), X (5), XI (5-6); (15) rajin membaca-menulis: pasal V (2, 4, 5), IX (7), (16) kepedulian terhadap persekitaran: pasal IX (7); (17) kepedulian terhadap masyarakat: pasal III (4), IV (7); (18) bertanggung jawab: semua pasal.

Ceramah, tanya-jawab, dan diskusi merupakan metode yang digunakan dalam penyampaian materi penerapan pendidikan budi pekerti kelompok sasaran. Pelaksana PkM menyampaikan materi secara jelas lagi terperinci, selanjutnya dilakukan kegiatan tanya-jawab. Peserta PkM terlihat begitu antusias, serta aktif dalam pelaksanaan kegiatan.

Sesi diskusi menjadi menarik. Pasalnya, para peserta banyak mengajukan pertanyaan dan keluhan berkenaan dengan anak-anak mereka yang cenderung kurang baik karakternya dalam kehidupan sehari-hari. Berkenaan dengan itu, peserta meminta solusi kepada pelaksana tentang cara mengatasi perilaku negatif anak-anak mereka. Selesai diskusi dilanjutkan dengan wawancara yang mendalam tentang kasus-kasus yang dihadapi peserta dalam menghadapi anak-anak mereka. Kegiatan itu dilaksanakan untuk menganalisis perubahan pemerolehan materi, keterampilan penerapan, serta sikap kelompok sasaran selesai dilakukan pelaksanaan aktivitas sosialisasi.

Kegiatan PkM ini menunjukkan dampak yang positif. Hasil itu diketahui dengan meningkatnya pengetahuan, pemahaman, keterampilan, dan sikap kelompok sasaran mengenai nilai-nilai budi pekerti (karakter) sekaligus cara penerapannya bagi anak-anak setiap rumah tangga dengan memanfaatkan khazanah budaya daerah yang ada di lingkungan mereka sendiri.

Seperti dikemukakan terdahulu, tolok ukur yang digunakan untuk menentukan hasil PkM ini ditunjukkan pada Gambar 1 berikut ini. 


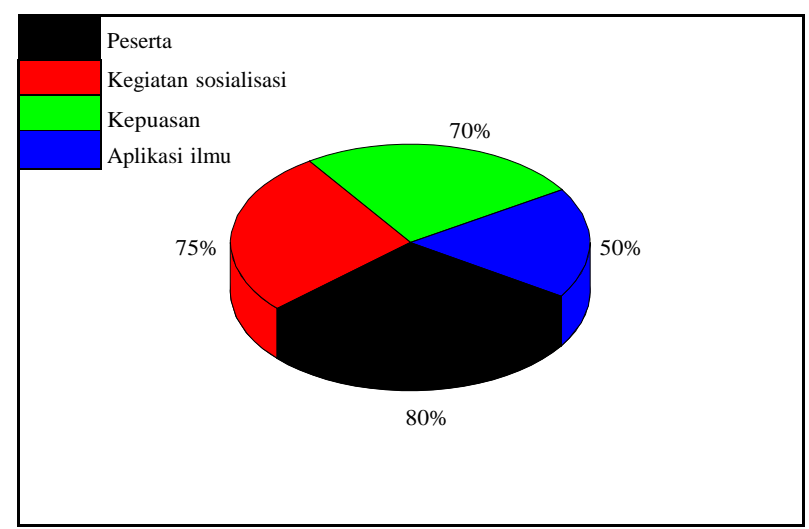

Gambar 1. Nilai tolok ukur keberhasilan kegiatan

Gambar 1 menunjukkan nilai yang menjadi patokan keberhasilan aktivitas PkM ini dengan nilai sebagai berikut: $80 \%$ undangan mengikuti $\mathrm{PkM}$ ini, $75 \%$ aktivitas sosialisasi terlaksana, $70 \%$ peserta menyatakan kepuasan tentang kegiatan sosialisasi, dan 50\% peserta dapat mengaplikasikan ilmu yang diperoleh selama pelatihan yang adanya pendampingan dari tim PkM.

Berdasarkan tolok ukur dengan indikator yang telah diperikan di atas, pelaksanaan PkM berhasil mencapai sasarannya. Hal itu disebabkan oleh semua indikator yang dikemukakan di atas terpenuhi. Pencapaian target kegiatan PkM ini disajikan pada Tabel 1 di bawah ini.

Tabel 1.

Perbandingan Target dan Capaian Kegiatan Sosialisasi

\begin{tabular}{clccccc}
\hline No. & \multicolumn{1}{c}{ Deskripsi } & \multicolumn{2}{c}{ Target } & \multicolumn{2}{c}{ Capaian } & Keterangan \\
& & Jumlah & $\%$ & Jumlah & $\%$ & \\
\hline 1. & Kehadiran peserta & 24 & 80 & 30 & 100 & Tercapai \\
2. & Keterlaksanaan kegiatan & 6 & 75 & 7 & 87 & Tercapai \\
3. & Kepuasan peserta & 21 & 70 & 30 & 100 & Tercapai \\
4. & Pengaplikasian ilmu & 12 & 50 & 26 & 86 & Tercapai \\
\hline
\end{tabular}

Tabel 1 memperlihatkan perbandingan antara target dan capaian kegiatan sosialisasi pendidikan karakter yang dilaksanakan. Dalam hal ini, semua indikator keberhasilan tercapai, bahkan melebihi target yang telah ditetapkan. Kenyataan itu membuktikan kegiatan sosialisasi melalui PkM ini tergolong sangat berhasil.

Ketercapaian tujuan kegiatan ini juga terlihat dari tujuh kriteria yang telah ditetapkan. Dalam hal ini, dibandingkan penguasaan peserta sebelum dan sesudah kegiatan sosialisasi tentang penerapan pendidikan karakter melalui kearifan lokal dalam lingkungan mereka, yang meliputi di dalam (1) lagu mengulik untuk menidurkan anak-anak, (2) pantun, (3) syair, (4) gurindam, (5) folklore, (6) pepatah dan tunjuk ajar, (7) tarian Melayu, (8) sandiwara rakyat. Kriteria serta hasil dari 18 nilai karakter sebagai berikut: 
JURNAL ANUGERAH, November 2020; Vol 2(2): 67 - 74

e-ISSN 2715-8179

(1) pengetahuan tentang 18 nilai karakter yang harus diterapkan, yakni sebelum kegiatan 12 orang $=40 \%$ dan sesudah kegiatan 26 orang $=86,7 \%$

(2) pemahaman dalam implementasi terhadap anak-anak, yakni sebelum kegiatan 10 orang $=33 \%$ dan sesudah kegiatan 28 orang $=93 \%$;

(3) pengetahuan dan penerapan kearifan lokal pada anak-anak, yakni sebelum kegiatan 18 orang $=60 \%$ dan sesudah kegiatan 27 orang $=90 \%$;

(4) pemahaman berkenaan dengan local wisdom yang ada di masyarakat, yakni sebelum kegiatan 14 orang $=46,7 \%$ dan sesudah kegiatan 27 orang $=90 \%$;

(5) kemahiran penerapan nilai dalam pendidikan anak-anak di rumah tangga, yakni sebelum kegiatan 14 orang $=46,7 \%$ dan sesudah kegiatan 26 orang $=86,7 \%$;

(6) kesediaan, kemantapan bersikap, dan bertanggung jawab memberi contoh serta tauladan kepada anakanak, yakni sebelum kegiatan 24 orang $=80 \%$ dan sesudah kegiatan 30 orang $=100 \%$;

(7) kemahiran dalam memberikan contoh serta tauladan kepada anak-anak di dalam keluarga, yakni sebelum kegiatan 21 orang $=70 \%$ dan sesudah kegiatan 30 orang $=100 \%$.

Perbandingan ketercapaian tujuan aktivitas PkM (antara sebelum dan setelah kegiatan) disajikan pada Gambar 2 di bawah ini.

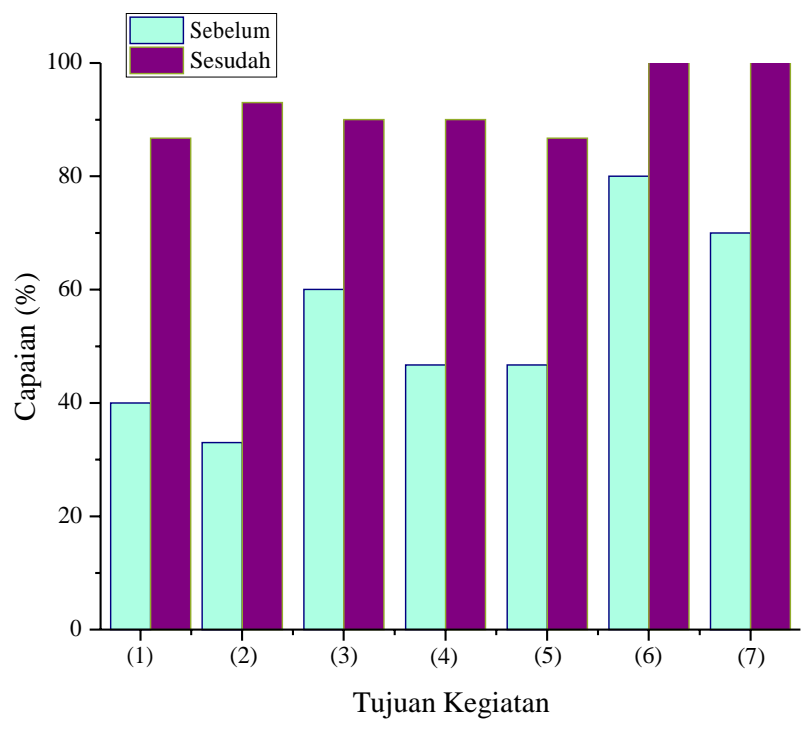

Gambar 2. Perbandingan ketercapaian tujuan kegiatan

Gambar 2 menunjukkan perbandingan ketercapaian tujuan kegiatan antara sebelum dan sesudah pelaksanaan kegiatan dalam penerapan 18 nilai karakter yaitu (1) pengetahuan dan penerapan, yang sebelumnya $40 \%$ menjadi $86,7 \%$, (2) pemahaman dalam implementasi terhadap anak-anak, yang sebelumnya $33 \%$ menjadi $93 \%$, (3) pengetahuan dan penerapan kearifan lokal pada anak-anak, yang sebelumnya $60 \%$ menjadi $90 \%$, (4) pemahaman local wisdom dalam budaya masyarakat, yang sebelumnya 46,7\% menjadi $90 \%$, (5) kemahiran penerapan untuk membudayakan nilai-nilai kepada anak-anak, yang sebelumnya 46,7\% menjadi 86,7\%, (6) kesiapan, kesadaran, serta tanggung jawab menjadi contoh serta tauladan bagi anak-anak, yang sebelumnya $80 \%$ menjadi $100 \%$, dan (7) kemahiran dalam memberikan contoh serta tauladan bagi anak-anak, yang sebelumnya $70 \%$ menjadi $100 \%$. Berdasarkan hasil tersebut, ketercapaian tujuan kegiatan meningkat dengan memperhatian perbandingan sebelum kegiatan dengan sesudah kegiatan. Hal ini 
menunjukkan keberhasilan kegiatan pengabdian masyarakat tentang penerapan pendidikan karakter melalui kearifan lokal.

Dengan terjadinya peningkatan terhadap pengetahuan, dalam pemahaman, dalam kemahiran, serta sikap peserta terhadap 18 nilai karakter serta kiat menerapkannya pada anak-anak dengan berpedomankan local wisdom dan local genius yang ada di dalam masyarakat, dapat dikatakan bahwa kegiatan PkM ini berhasil mencapai tujuan yang telah ditargetkan. Diharapkan masyarakat sasaran konsisten menerapkan pengetahuan, pemahaman, dan pengalaman mereka dalam mendidik anak-anak di rumah tangga dan lingkungan mereka.

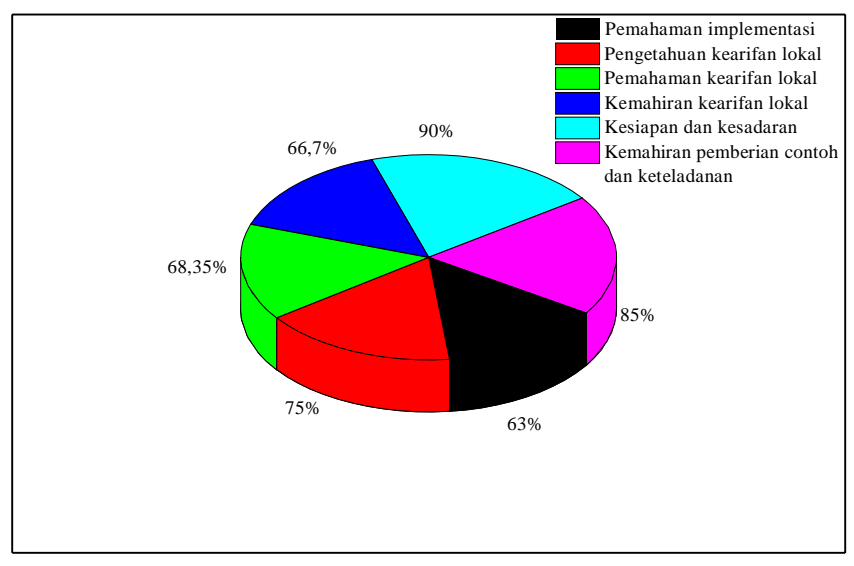

Gambar 3. Nilai rata-rata ketercapaian tujuan kegiatan

Gambar 3 menunjukkan nilai rata-rata yang diperoleh dari perbandingan ketercapaian tujuan kegiatan sebelum dan sesudah dilaksanakannya kegiatan sosialisasi tentang penerapan pendidikan karakter melalui kearifan lokal dalam lingkungan masyarakat yaitu (1) implementasi pemahaman terhadap 18 nilai karakter pada anak-anak, yakni 63\%; (2) penerapan pendidikan karakter kepada anak-anak melalui pengetahuan tentang kearifan lokal, yakni 75\%; (3) local wisdom yang tersedia di masyarakat yang dapat dijadikan pedoman tentang nilai-nilai karakter, yakni 68,35 ; (4) keterampilan penularan nilai karakter dalam kearifan lokal tersebut kepada anak-anak, yakni 66,7\%; (5) kesediaan, pemahaman, serta bertanggung jawab memberikan dan menjadi contoh serta tauladan dalam keluarga, yakni 90\%; (6) kemahiran memberi contoh serta tauladan berkenaan dengan tingkah laku berkarakter kepada anak-anak dan seluruh anggota keluarga, yakni $85 \%$.

Berdasarkan hasil tersebut, tujuan kegiatan tentang penerapan pendidikan karakter melalui local wisdom dan local genius yang tersedia di masyarakat tercapai melalui kegiatan PkM ini. Dengan demikian, diharapkan masyarakat sasaran konsisten menerapkan pengetahuan, pemahaman, dan pengalaman mereka dalam mendidik anak-anak di rumah tangga dan lingkungan mereka.

\section{Kesimpulan}

Berdasarkan pemaparan di atas, hasil PkM ini menunjukkan adanya peningkatan nilai pengetahuan, nilai pemahaman, nilai kemahiran, serta nilai sikap peserta sasaran berkenaan dengan esensi serta mustahaknya nilai karakter yang diimplementasikan di dalam pendidikan keluarga. Kenyataan itu mengindikasikan bahwa kegiatan PkM ini menunjukkan keberhasilan dalam (1) memberikan sosialisasi berkenaan dengan pendidikan karakter di dalam keluarga yang selama ini umumnya belum dipahami oleh warga masyarakat sasaran dan (2) meningkatkan nilai pengetahuan, nilai pemahaman, nilai kemahiran, serta nilai sikap masyarakat sasaran PkM, yang memang seyogianya berperan sebagai contoh serta tauladan dalam 
JURNAL ANUGERAH, November 2020; Vol 2(2): 67 - 74

e-ISSN 2715-8179

penerapan karakter yang unggul kepada keluarga mereka, lebih-lebih kepada anak-anak. Alhasil, karakter baik itu direalisasikan dalam bersikap, berucap, serta bertindak di dalam kehidupan sehari-hari.

Berhubung dengan capaian di atas, kegiatan PkM ini seyogianya berlanjut di dalam masyarakat yang belum mendapatkan sosialisasi sehingga penerapan nilai karakter semakin luas di kalangan masyarakat. Dengan cara itu, antara lain, pendidikan karakter akan tersebar secara luas di masyarakat sehingga pada gilirannya akan terbentuk generasi muda yang berkarakter baik dan hebat.

\section{Saran}

Berdasarkan kegiatan PkM yang dilakukan pada masyarakat Kelurahan Kampung Bugis, Kecamatan Tanjungpinang Kota, diajukan saran sebagai berikut.

1.Pendidikan karakter mesti terus dimasyarakatkan di Tanjungpinang sebab masih banyak warga yang belum memahiri metode penerapannya di lingkungan pendidikan keluarga (informal).

2. Kearifan lokal warga sebaiknya selalu digali dan diterapkan sehingga implementasi pendidikan karakter betul-betul berasal dari nilai kebudayaan warga yang bersangkutan sehingga anak-anak lebih mudah menyerap nilai-nilai tersebut.

\section{Ucapan Terima Kasih}

Tim PkM mengucapkan terima kasih kepada Lembaga Penelitian dan Pengabdian kepada Masyarakat, Universitas Maritim Raja Ali Haji, yang mendistribusikan dana bagi tim untuk melakukan aktivitas sosialisasi dalam PkM ini.

\section{Referensi}

Departemen Pendidikan Nasional [Depdiknas]. (2003). Undang-Undang No. 20 tahun 2003 Tentang Sistem Pendidikan Nasional. Jakarta, Indonesia: Depdiknas.

Haji, R. (1988). Syair Abdul Muluk (S. Syamsiar, ed.). Pekanbaru: Bagian Proyek Penelitian dan Pengkajian Kebudayaan Melayu, Penelitian dan Pengkajian Kebudayaan Nusantara, Departemen Pendidikan dan Kebudayaan.

Kementerian Pendidikan Nasional. (2010). Pengembangan pendidikan budaya dan Karakter bangsa. Jakarta.

Lickona, T. (2004). Pengertian pendidikan karakter. Jakarta.

Malik, A. (2014). Kehalusan budi memartabatkan jati diri: tinjauan karya-karya Raja Ali Haji. Tanjungpinang: Milaz Grafika.

Malik, A. (2015). Nilai-nilai budi pekerti dalam karya raja ali haji. Jurnal Peradaban Melayu, 10, 96-107.

Malik, A., Dahnuss, D., \& Shanty, I. L. (2019). Implementasi pendidikan karakter di lingkungan keluarga. Jurnal Anugerah, 1(1), 1-7.

Malik, A., \& Shanty, I. L. (2017). Personal character index in the works of raja ali haji. The International Journal of Social Science, 58(1), 22-34.

Malik, A., \& Shanty, I. L. (2019). Character indexes of the people in the works of raja ali haji. Advances in Social Science, Education and Humanities Research, 295, 148-151.

Pusat Kurikulum. (2010). Pedoman pengembangan pendidikan budaya dan karakter bangsa. Jakarta. 